\title{
BIBLIJNA ORIENTACJA MEDYTACJI PACHOMIAŃSKIEJ
}

Medytacja jako szczególny rodzaj modlitwy nadającej życiu ludzkiemu wymiar głębi przeżywa w ostatnich latach swój kolejny renesans. Zainteresowanie nią w sytuacji nieustannego zabiegania, rozproszenia myśli i niezdolności do głębszego skupienia i refleisji zwraca ponownie uwage i nadzieje wielu ludzi, rozczarowanych metodami Dalekiego irschodu, w stronę bogatego dziedzictwa tradycji chrześcijańskiej. Odkryto więc na nowo wartość "Cwiczen duchownyeh" św. Ignacego Loyoli, zainteresowano się metodami proponowanymi przez św. Franciszka Salezego, Filipa Neri i mistrzów Karmelu, Jana od Krzyża i Teresy z Avila. Z czasem sięgano coraz głębiej do dorobku pisarzy średniowiecza, by następnie zstąpić do fundamentów chrześcijaństwa 1 odczytać duchowe bogactwo myśli patrystycznej.

Celem niniejszego opracowania jest refleksja nau zjawiskiem medytacji mnichów egipskich ze szkoły św. Pachomiusza. Egipt bowiem stał się kolebką monastycyzmu chrześcijańskiego, zwróconego zupełnie ku Biblii 1 naśladowaniu Chrystusa. W nauczaniu św. Pachomiusza 1 jego bezpośrednich następców odnajdujemy nie tylko całą żarliwość anachoretów, ale $i$ mądre i wciąż aktualne zasady formacji duchowej kolejnych generacji mnichów. Nauczanie to w swoim czasie wywarło znaczny wpływ na powstanie i kształt monastycyzmu w Kościele zachodnim. Warto więc przyjrzeć się medytującym pachomianom z oddali wieków, by uczyć się od nich obcowania z Pismem świętym.

\section{I. etrmologia slowa "Meditowá́", "MedytaCja"}

Słowo "medytować", "medytacja" wywodzi się z łacińskiego "me-

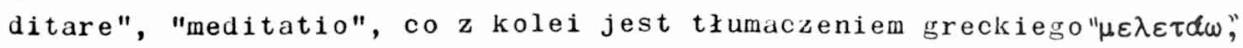

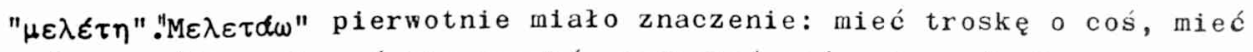
coś na myśli, oddawać się czemuś, usiłować coś osiągnąć. Z czasem wyrażenie to w środowisku retorów zyskało znaczenie: éwiczyć się w mówieniu, studiować lub wygłaszać jakąś mowę, deklanować. li tym właśnie 
znaczeniu zostało przejęte przez język łaciński.

W kręgu kultury łacińskiej słowa "meditare", "meditatio"- okazały się nad wyraz użyteczne dla wyrażenia takich czynności jak: posługiwać się bronią, memoryzować rolę teatralną, partyturę czy mowę głoszoną w senacie lub w trybunale. Częściej jednakże "meditatio", to przemówienie młodych retorów o charakterze ćwiczebnym, nastawione na dostarczenie rozrywki ludowi ${ }^{1}$.

W tym właśnie znaczeniu słowa "meditare", "meditatio" uży św. Hieronim dla wyrażenia greckiego " $\mu \varepsilon \lambda \varepsilon \tau đ \omega ", ~ " \mu \varepsilon \lambda \varepsilon \tau \eta "$, te zaś zostały użyte przez tłumaczy Septuaginty dla wyrażenia hebrajskiego słowa "hägăh". Słowo to jednak też nie jest jednoznaczne; jego bowiem przedmiotem były: wargi, gardło, podniebienie, a także serce i duch.

Zawartość treściowa słowa "hāgāh" powstała w oparciu o analogie obserwowane w przyrodzie. Słowem "hāgāh" wyrażano głuche, monotonne gruchanie gołębicy /por. Iz 38, 14; 59, 11/, czy gardłowe, głębokie pomruki lwa, kładącego zwycięską łapę na świeżo upolowanym zwierzęciu /por. Iz 31, 4/. Jeżeli jednak poinruki lwa, wyrażające jego miażdżącą siłę, budzącą trwogę i respekt nadawały się do zobrazowania potęg1 Boga, to w przypadku gołębicy jej monotonne gruchanie posłużło prorokowi do wyrażenia stanu ducha człowieka cierpiącego, udręczonego, złamanego na duchu, zbolałego i chorego; nie ma on siły, by krzyczeć, może jedynie wzdychać i jęczeć.

Właśnie takie znaczenie ma słowo "hāgāh" w odniesieniu uo Moabitów, którzy "zawodzą" na widok zburzonego miasta/Iz 16, 7; Jr 48, 31/. Z tego samego powodu także naród wybrany "wzdycha" do Tego, który go ukarał /Iz 26, 16/. U Ezechiela /2, 10/ czasownik "hāgäh", przyjmując formę rzeczownikowa "hل̈ğtun", został użyty dla wyrażenia narzekania, wzdychania i biadania, którymi została zapisana księga ukazana prorokowi. Podobnie wyrażenie "hāgāh" występuje w psalmie $/ 1,2 / i$ odnosi się do sprawiedliwego, który nad Prawem Fana "r o z m y ś 1 a" dniem i nocą; w innym psalmie/2, 1/ wyrażenie to oddaje postawę narodów, które "knują daremne zamysły" przeciw Bogu i Jego Pomazańcowi.

W Biblii są jednak teksty, w których słowo "hāgāh" użyte zostało

1 Por.E. Forcellini, Lexicon Totius Latinitatis IV, Prati 1868, $78 \mathrm{nn}$. 
w sensie duchowym, liturgicznym. W tym znaczeniu spotykamy je w Księdze Jozuego /1, 8/. Bóg poleca Jozuemu działać ściśle według Prawa, które ma być zawsze na jego ustach, wa je liedytować w dzień $\mathrm{i}$ w nocy, by spełnić wszystko, co tam jest napisane.

Można więc powiedzieć, że medytować to znaczy cicho, samemu sobie powtarzać jakiés zdanie czy tekst tak, by wrósł w serce. Przedmiotem medytacji jest sprawiedliwość Boga, Jego mądrość, Prawo i przykazania, a także Jego dzieła. Czynność zaś medytacji wykonuje język, wargi i usta sprawiedliwego; podmiotem właściwym jest jednak zawsze sam człowiek, świadomie podejmujący czynność przyswajania sobie Prawa, by uczynić je wewnętrznym przewodnikiem w codziennym wybieraniu właściwej drogi $i^{2}$.

\section{MEDYTACJA W ŚRODOWISKU ANACHORETÓW}

Taki właśnie biblijny sens słowa "hāḡāh" odnajdujemy w medytacji anachoretów. Medytowali oni słowo Boże dniem $i$ nocą, powtarzali je bezustannie, aż dochodzili do posiadania Biblil w sobie. Jednakże do wyżej omówionego pojęcia monotonnego powtarzania tekstów świętych dodali oni jeszcze pojęcie przezuwania. Równiez w tym wypadku natchnieniem była im Biblia, jej egzegeza alegoryczna oraz zwyczajna obserwacja przyrody.

Pojęcie przeżuwania pojawia się w Prawie w kontekście postanowień o zwierzętach czystych 1 nieczystych. Do pierwszej grupy zaliczano zwierzęta charakteryzujące się przeżuwaniem i rozdzielonym kopytem; tylko z tych zwierząt można było składać Bogu ofiary i spożywać z nich mięso. Należały tu zwłaszcza zwierzęta domowe, takie jak: wół, owca, koza. To właśnie te zwierzęta w egzegezie alegorycznej stały się obrazem człowieka, który czytając Pismo św., poprzez sens wyrazowy dochodzi do sensu duchowego.

Klemens Aleksandryjski, komentując ten przepis Prawa, pisał:

"kopyto rozdzielone oznacza sprawiedliwość słuszną, która przeżuwa pokarm właściwy sprawiedliwości, to

2 Por. H. Ringgren, I İ̄̄āh, w: Theologisches Worterbuch zum Alten Testament II, Stuttgart 1974, 343-347; E. von Severus, Das Wort "Meditari" im Sprachgebrauch der Heiligen Schrift, w: "Geist und Leben" 
jest Słowo /Logos/... Sprawiedliwy, mając Słowo w ustach, przeżuwa pokarm duchowy"3?

Przepis Prawa o zwierzętach czystych w sensie alegorycznym komentował także Qrygenes w słowach:

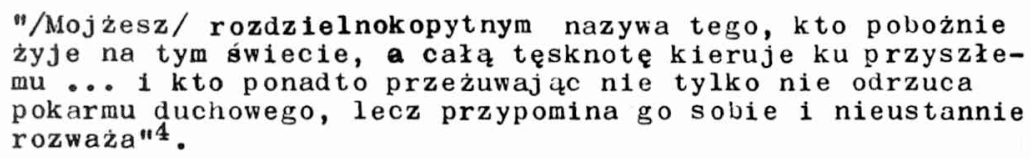

Ów sugestywny obraz duszy "przeżuwającej" bardzo szybko stał się własnościá środowisk monastycznych, stał się zachętą do obserwacji przyrody na własną rękę i odczytywania w niej Bożej nauki w sposób własny $i$ oryginalny.

Jeden z apoftegmatów koptyjskich przypisuje Antoniemu taką właśnie refleksję opartą na poczynionych obserwacjach z życia zwierząt. otóz Antoni porównuje sposób pobierania pokarmu przez konia i wielbłąda oraz zauważa, że koń jada dużo 1 o każdej porze, wszystko jednak szybko traci. Wielbłąd natomiast zjada mało, w stajni jednak przeżuwa wszystko tak długo, aż pokarm doskonale zasymilowany przeniknie do każdej części ciała. Z tych zaś obserwacji Antoni wyprowadza naukę:

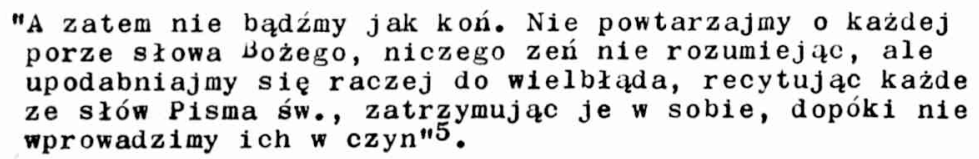

Podobną myśl wyraził św. Makary Wielki, według którego właśnie czynność przezuwania powoduje rozprowadzenie pokarmu po całym ciele

26/1953/365-375.

3 Clemens Alexandrinus, Paedagogus III 11, 76, SCh 158, 148; Stromata VII 109, 2, SCh 38, 117.

4 Origenes, Selecta in Leviticum, PG 12, 401; por. In Leviticum homilia 7, 6, PG 12, 489; In Numeros homilia 27, 1, PG 12, 780-782.

5 E. Amélineau, Monuments pour servir à l'histoire de l'Egypte chrétienne au IV siècle, Paris 1889, 39-40. 
owcy, która rozkoszując się tym, cała promienieje błogim zadowoleniem ${ }^{6}$.

Koptyjski żywot Jana zwanego Karłen, żyjącego na pustyni egipskiej wkrótce po śmierci Pachomiusza, opowiada, że Jan "oddawał się on całym sercen medytacji Pisma św., przeżuwając je w pamięci i czynił̨c je swoją modlitwa, podobnie jak owca "medytująca", skupiając się na słodyczy ich znaczenia" ${ }^{7}$. Podobnie miał postępować niejaki Abraham eremita, który uczestnicząc w liturgii starał się zapamiętać treść czytań po to, by medytować je także poza kościołem ${ }^{8}$.

Z przytoczonych przykładów iidać, że pojęcie przeżuwania stało się bardzo ważnym czynnikiem wzbogacenia pojęcia medytacji jako wzdychania, recytowania słowa Bożego. Obraz medytacji jako przeżuwania wyrażal aspekt karmienia się słowem Bożym, a zarazem uzmysławiał tajemnicę przenikania Biblii do wnętrza człowieka, powodując jego przemianęnawrócenie.

\section{SPECYFIKA MEDYTACJI PACIONIIAŃSKIEJ}

Uwagi powyższe wydają się byé niezbędnym fundamentem dla rozważań dotyczących miejsca i roli medytacji w środowisku mnichów św. Pachomiusza. Wiadomo bowiem, że sam wielki organizator życia wspólnotowego mnichów wyrósł na tradycjach anachoretów, wiele z nich przejmując dla życia we wspólnocie prawie bez zmian.

Św. Pachomiusz /287-346/ - Egipcjanin,, podobnie jak współczesny mu Wielki Antoni - pod wpływem dobroci okazanej mu przez chrześcijan więzieniu, zapragnął oddać się cały nieznanemu "Bogu wszy-

T'ance, 152-153.

$7 \quad$ Tamże, 333.

8 Vita S. Abrahae Erenitae 1, PL 73, 283: "Beatus Abraham... ecclesiarum conventicula iugicer Prequentabat, et quaecumque ibi ex divinis Scripturis recitabantur, aurem libenter accomodans audiebat, et in cordis sui meioriam ita recondebat, ut etiam cum absens esset ea quae didicerat meditatione intensissima ruminaret". 
stkich świętych", a zarazem postanowił służyć ludziom. Po chrzcie rzeczywiście jakiś czas posługiwał gorliwie chorym, potem jednak udał się do sławnego w okolicy anachorety Palamona. W ciagu 7 lat życia anachorety miał okazję zobaczyć niebezpieczeństwa, jakie grożą pustelnikowi; rosła w nim świadomość, ze powołaniem jego będzie uporzadkowanie 1 pogłębienie życia monastycznego. Po pierwszej nieudanej próbie stworzył w roku 320 prężną wspólnotę w Tabennısi, na bazie pewnego regulaminu, którego fundament stanowiło posłuszeństwo. irkrótce powstały dalsze fundacje, tak że w roku 346, w momencie śmierci fundatora dzieło jego liczyło ok. 5000 mnichów w 9 klasztorach; prócz tego istniały już 2 klasztory żeńskie ${ }^{9}$.

Wiszystkich mnichów obowiązywała równość względem przepisów Reguły, wszyscy nosili jednakowe odzienie, mieszkali w identycznych celach, a w nich mieli jednakowe proste posłania, jadali razem to samo ubogie pożywienie. Obowiązywała wszystkich bez wyjątku praca i troska o powierzone sobie dobro wspólnoty, ale szczególnie doniosłą rzeczą było wymaganie wzajemnej troski o postęp duchowy współbraci, wspieranie się w dążeniu do doskonałości, odpowiedzialność za drugich, a także poczucie umiaru i realizmu w zakresie praktyk ascetycznych, oraz wrażliwość na ludzkie potrzeby i wyrozumiałość dla ludzkich słabości 1 upodobañ ${ }^{10}$.

Fundamentem tak przeżywanego braterstwa było ustawiczne odwoływanie się do Biblii, która stanowiła zasadniczą regułę społeczności pachomiańskiej. Uczono się jej entuzjastycznie na pamięć, studiowano ją $i$ medytowano, modlono się jej słowami, zwłaszcza psalmów, a nawet - tylko po to, by o każdej porze osobiście z niej korzystać - wymagano od mnichów sztuki czytania 1 pisania ${ }^{11}$.

9 D. J. Chitty, The Desert a City. An Introduction to the Study of Egyptian and Palestinian Monasticism under the Christian Empire, Lond on 1966, 24 nn.; H. Bacht, Pakhome - der Grosse "Adler", "Geist und Leben" 22/1949/367-382; tenże, Antonius und Pachomius. Von der Anachorese zum Conobitentum, "Studia Anselmiana" 38/1956/ 66-107.

10 H. Bacht, Zur Typologie des koptischen Monchtums: Pachomius und Evagrius, w: K. Wessel/red./, Christentum am N11, Recklinghausen $1964,142-157$.

11 Praecepta 139-140, ed. A. Boon, Pachomiana Latina, Louvain 1932, 49-50: "Et si litteras ignorabit, hora prima et tertia et sexta vadet ad eum qui docere potest et qui ei fuerit delegatus, et stabit ante illum, et discet studiosissime cum omni gratiarum 
Tym niemniej ustawodawstwo pachomiańskie dotyczace medytacji jest jednak nad wyraz skromne. Nie określa ono żaunych zasad lotyczących sposobu medytowania, lecz jedynie ustala, kiedy należy nedytować. Pachomianie medytowali więc w drodze do pracy ${ }^{2}$, gdy szli na wspólne modlitwy ${ }^{13}$, lub do refektarza ${ }^{14}$. Medytował także trębacz wzywający na modlitwy $i$ posiłki ${ }^{15}$, medytował 1 mnich wyznaczony do rozdawania "tragematia" wychodzącym z refektarza ${ }^{16}$. Hedytowało się także przy pracy, zwłaszcza manualnej, wykonywanej samotnie w celi. Nie bez znaczenia był tu fakt, że do pracy wychodziło się po liturgii porannej, której praca była jakby przedłużeniem, dlatego mnich pachomiański pracując zobowiązany był medytować lub milczećc ${ }^{17}$.

Szczególna, wrecz liturgiczna atmosfera panowała w piekarniach klasztornych, gdzie skrupulatnie przestrzeganc głębokiego skupienia, jak o tym świadczy odpowiedni przepis: "Kiedy wlewają wodę do mąki i wyrabiają ciasto, niech jeden nie odzywa się do drugiego. Gdy rankiem wsadzają na desce chleb do pieca lub składają go do koszów, za-

actione. Postea vero scribentur ei elementa syllabae, verba ac nomina, et etiam nolens legere compelletur" /... "Et omnino nullus erit in monasterio qui non discat litteras et de scripturis aliquid teneat /.../".

12 Praeceptum 59, Boon 31: "Cumque universae domus in unum Puerint congregatae, rioris domus praepositus olines antecedet, et pergent iuxta ordineil domorum et hominum singulorum; nec loquentur mutuo, sed unusquisque de scripturis aliquid meditabitur".

13 Praeceptum 3, Boon 14: "Cumque audierit vocem tubae ad collectam vocantis, statim egrediatur cellula sua, de scripturis aliquid meditans usque ad ostium conventiculi".

14 Praeceptum 28, Boon 20: "Dimissa collecta singuli egredientes usque ad cellulas suas vel usque ad vescendi locum de scripturis aliquid meditabuntur".

15 Praeceptum 36, Boon 22: "Wui percutit et ad vescendum congregat eratres, meditetur in percutiendo".

16 Praeceptum 37, Boon 22: "Qui ante fores convivii egredientibus erogat fratribus tragematia, in tribuendo meditetur aliquid de scripturis".

17 Praeceptum 60, Boon 32: "Operantes nihil loquentur saeculare, sed aut meditabuntur ea quae sancta sunt, aut certe silebunt". 
chowają podobne milczenie i dopóty będa śpiewać psalmy 1 coś z Pisma św. aż ukończą robotę $e^{18}$.

Praca, zwłaszcza manual na stanowiła ważny środek osobistej ascezy mnicha, a medytacja znakomicie ja uzupełniała. Praca rąk pomagała zwalczać senność ogarniającą podczas nocnych czuwaŕ, medytacja zaś czyniła je duchowym czekaniem na przyjście Pana, ku któremu serce mnicha wyrywało się w modlitwie. Medytacja właśnie tę modlitwę przygotowywała.

Jeden z żywotów Pachomiusza opowiada o początkach pobytu we wspólnocie młodego Teodora, który z czasem miał się stać mężem opatrznościowym dla dzieła Pachomiusza. Otóż Teodor siedział w celi i splatał liny, recytując przy tym wersety z Pisma św. Ile razy odczuwał potrzebę modlitwy, przerywał pracę $1 \bmod 11 \nmid \operatorname{sie}^{19}$.

Medytacja była też uważana za bardzo skuteczny środek przeciw gnuśności, melancholi1 1 depresji duchowej ${ }^{20}$. Uważano też, że przez medytowanie mnich przygotowuje sie do godnego udziału w liturgi1 niedzielnej Mszy św. ${ }^{21} \mathrm{z}$ czasem utarło się przekonanie o skuteczności medytacji przeciw atakom złego ducha; nawet jeśli medytujący mnich nic nie rozumiał z powtarzanych słów, juz samo to, ze na wargach miał Boże słowo, czyniło go niedostępnym dla wściekłych ataków demonów 22

18 Praeceptum 116, Boon 44.

19 Sancti Pachomil Vita Bohairice scripta 34, wyd. i tłum. franc. L. Th. Lefort, Les Vies Coptes de saint Pachồme et ses premiers successeures, Louvain 1943, 105.

20 Ilustracją niech będzie pewien epizod z zycia Wielkiego Antoniego. Oto popadłszy w zniechęcenie i wielką ciemność duchową, prosił Boga o radę. Chwilę potem, wyszedłszy na zewnątrz zobaczył kogoś, "kto siedział i pracował, potem wstawał od pracy 1 modlił się, a potem znowu siadał i plótł linę, i znów powstawał do moditiwy $\% .$. Wtedy Antoni otrzymał pouczenie: "Tak rób, a będziesz zbawiony". Księga starców. Ojcowie zywi 5, wyd. M. Starowieysk1, Kraków 1983, 49.

21 Uczeń abba Marcelina z Tebaidy opowiadał o swym mistrzu, ze ten każdej niedzieli, gdy miał wyjść na niedzielną Mszę ów., przygotowywał się starannie, a idąc recytował z pamięci wersety z Pisma św., aż doszedł do kościoła. Por. Manuskrypt Coislin 567, w: L. Mortari, Vita e Detti dei padri del deserto 2, Roma 1975, 252 .

22 Manuskrypt Coislin zawiera opowiadanie /nr 626/ o tym, ze owca, zjadłszy na pustyni coś niewłaściwego, ratuje się, szukając odpowiednich ziół. Tak i człowiek: broni się przed atakami demonón medytując Pismo św., "albowiem demony nie mogą słuchać, gdy ktoś 
Pachomianie więc, podobnie jak $i$ anachoreci, traktowali medytacje jako swoiste, głęboko intymne obcowanie ze słowem Bożym. Polegało to na recytowaniu półgłosem wersetów, powtarzaniu bez końca tych samych słów, aż do osiągnięcia stanu charakterystycznej nieczułości na ich treść informacyjną, aż do popadnięcia w pewien rodzaj transu, przenoszącego mnicha w czarowny świat upojeń mistycznych. Medytacja pachomiańska więc to przeżuwanie słowa Bożego, to swoiste rozdrabnianie go, stopniowe rozgryzanie $i$ asymilacja. lais wi ̨c medytacja mnichów pierwszych generacji, a wśród nich $\mathbf{i}$ pachomian, nie miała w sobie nic z rozmyślania rozumianego jako modlitwa myślna. Medytacja to powna aktywność fizyczna i umysłowa, to recytacja tekstów biblijnych, przygotowujących wnętrze człowieka do dialogu modlitwy. Medytacja, dostarczając treści dla modlitwy, równocześnie eliminowała wrażenia uboczne, pomagała w koncentracji, wyciszała 1 uspokajała, stwarzała klimat 1 natchnienie do modlitwy promieniującej niejako spontanicznie z serca nasyconego Bogiem.

Wyraził to w sposúb niezwykle trafny orsiesi /305-390/, kolejny ñastępca Pachomiusza w kierowaniu wspólnotą, gdy w swym "Liber" pisał:

\footnotetext{
"Troszczmy się o czytania i memoryzowanie Pisma św. oraz poddawajmy je ciagłej medytacji, pomni na to, co napisane: "L owocu ust swoich człowiek się syci" /Prz 13, 2/ ... oto co nas prowadzi ku życiu wiecznemu, które przekazał nam ojciec nasz, nakazując nam nieustannie medytować ... byśmy przeżuwając w ustach słowo Boże, posiedli wiare" 23 .
}

IV. MEDYTACJA A MEMOHYZACJA BIBLII

Medytacja wyuagała od mnicha pachomianskiego pamięciowego opanowania Biblii, gdyż chodziło o recytację poza domem, przy pracy,

wielbi Chrystusa" /Mortar1 s. 261//../ "Wystarczy, żebyś czytał - pouczał pewien starzec współbrata - zaklinacz wężów też nie zna wałi słów, jakie wypowiada, ale wąż słucha 1 rozumie. Tak jest i z nami: jeśli nawet nie znamy sensu słów, które wypowiadamy, to przeciez demony słuchają i oddalają się w popłochu"/Mortari, Roma 1980, 109/.

23 Liber Orsiesii 51-52, ed. A. Boon /Pachomiana Latina, Louvain 1932/, 143-144. 
lub w drodze do niej. W ustawodawstwie pachomiańskim znajdujemy przepisy regulujące $i$ tę sprawę.

Od kandydata do zakonu wymagano nauczenia się na pamięć "Ojcze nasz" i tyle psalmów, ile zdołał"24. Inny przepis wymagał od kandydata pamięciowego opanowania "duudziestu psalmów lub dwóch listów Apostoła, albo innej części Pisma"25. Wreszcie postanawiano, że "w klasztorze nie będzie nikogo, co by nie umiał czytać i pisać i nie znał na pamięć bodaj części Pism świętych, co najmniej Nowego Testamentu i Psałterza"26. W ten sposób każdy z pachomian posiadał nie tylko pewną ogładę religijną, ale jeszcze uzyskiwał niebagatelne na owe czasy wykształcenie, gdy analfabetyzm był prawie powszechny. Idea, jaką kierował się prawodawca była dalekowzroczna: mnich pachomiański mógł osobiście i o każdej porze korzystać z Biblii; Biblię się komentowało aż 5 razy w tygodniu, podczas tzw. katechez, które miały raczej charakter wielkich konferencji biblijno-ascetycznych. Mnich św. Pachomiusza nie był więc ciemnym fanatykiem, gotowym na skinienie do udziału w walkach z poganami czy w popieraniu gorszących rywalizacji, których w tantych czasach nie brakowało. Mimo to jednak pamięciowe posiadanie Biblii miało tę dobrą stronę, że była ona niejako zawsze pod ręką.

W tym wypadku, zresztą nie jedynym, pachomianie wzorowali się na anachoretach, dla których recytowanie Biblii z pamięci miało podstawowe znaczenie: był to bowiem rodzaj rozmowy z Bogiem twarzą w twarz, swoista komunta słowa Bożego 27 . Uczyli się więc Pisma św. ze szczerym entuzjazmem, ale 1 ze czcią nabożną, tępiono natomiast jako niestosowne i nieprzyzwoite memoryzowanie wyczynowe, obliczone na zyskanie podziwu otoczenia, a co najmniej uznania we własnych

24 Praeceptum 49, Boon 25-26.

25 Praeceptum 139, Boon 49-50: "Qui rudis monasterium fuerit ingressus, docebitur prius quae debeat observare ..., et dabunt ei viginti psalinos vel duas epistulas apostoli, aut'alterius Scripturae partem".

26 Praeceptum 140, Boon 50.

27 Por. H. Bacht, Vom Umgang mit der Bibel im altesten Monchtum, "Theologie und Philosophie" 41/1966/557-566; G. M. Colombás, La Biblia en la Espiritualidad del monacato primitivo, "Yermo" $1 / 1963 / 3-20,149-170 ; E$. Von Severus, Zu den biblischen Grundlagen des Monchtums, "Geist und Leben" 26/1953/113-122. 
$\mathrm{oczach}^{28}$.

Także u pachomian do dziś zdumiewa łatwość, z jaką tworzyli zupełnie niezwykłe skojarzenia różnych tekstów, czasem tylko werbalnie zbieżnych ze sobą, nie wyrażających zasadniczej myśli, lecz - bywało - nawet ją nieraz zaciemniających. Przemówienia Pachomiusza, jak również $i$ jego następców, pełne są takich właśnie swobounych skojarzeń, zestawionych na zasadzie asocjacji, uderza w nich jednak łatwość 1 naturalność w przechodzeniu od Ksieggi Rodzaju do Ewangelii, od Psalmów do Proroków. Wszystko to było rezultatem ustawicznego przestawania z Biblią, która spożywana codziennie, przeżuwana nieustannie, przesycała soba całego człowieka, żywiła jego wiarę, stawała się zaczynem wewnętrznej przemiany, wyznaczając perspektywę życia wiecznego 29 .

Pachomianin przyjmował słowo Boże jako pokarm duchowy, chleb żywota, tak potrzebny człowiekowi, stosownie do słów Chrystusa: "Nie samym chlebem żyje człowiek, lecz każdym słowern, które pochodzi z ust Bożych"30. Mnich pachomiański także i pod tym względem był odpowiedzialny za współbraci. Reguła bowiem nakazywała uważnie słuchać konPerencji, które głosili przełożeni, polecała też, by bracia o tym, co usłyszeli, rozmawiali ze sobą, by pytali się wzajemnie, przypominali sobie, karmiąc się wzajemnie tym, czym sami żyli ${ }^{31}$.

28 Manuskrypt Coislin w opowiadaniu nr 518 przypisuje Antoniemu rodzaj testu, według którego nauczyć się Pisma św. na pamięć to znaczy uchwycić jego prawdziwy sens, jego treścią przesycić całe życie. Por. L. Nortari, Vita e Detti ..., dz.cyt.,248 n.

29 Orsiesi, Liber 51, Boon 143.

30 Orsiesi, Regulae, ed. L. Th. Lefort/Oeuvres de S. Pachôme et de ses disciples, Louvain 1956, CSCO 159/160, $85: " / \ldots$ / Prenons la parole de Dieu pour une nourriture de vie, col:me il est écrit: L'homme ne vit pas seulement de pain, mais c'est de toute parole sortie de la bouche de vieu que l'homme vivra".

31 Praecepta 19 et 138, Boon 17 i 49: "Mane per singulas domos, Pinitis orationibus, non protinus ad suas cellulas revertentur, sed conferent inter se quae praepositos audierint disputantes, et sic intrabunt cubicula"./... "Omne quod in conventu fratrum audierint disputatum, necessitate cogentur ut inter se replicent, ieiuniorum maxime tempore, quando a suis docentur praepositis". 
Niestety, z czasem zanikła ta zażyłość z Biblią, uważana przeciez za oryginalny znak rozpoznawczy pachomian, zabrakło ducha pierwotnej gorliwości, zabrakło też atmosfery biblijnej, pojawił się kryzys wierności ideałom, a w konsekwencji niebezpieczeństwo utraty wewnętrznej tożsamości. Nic dziwnego, że Teodor, któremu wypadło ratować ducha założyciela te właśnie sprawy wyliczał jako najważniejsze:
"Od czasów ojca naszego nie mieliśmy nic innego tak w sercu jak i na wargach, jak tylko słowo boże, słodsze od miodu $i$ miodowego plastra. Nie pragnęliśmy już żyć na ziemi, lecz świętować w niebie. Człowiek, który zmarzł na kość, usiłuje biec, aż dopadnie ognia, przy którym się ogrzeje i przyjdzie do siebie. Tak i my: bardziej szukaliśmy Boga, jego dobroć bardziej uka- zywała się nad nami, osładzając naszą duszę. A teraz - gdzie jesteśmy?"32

Z troską i niepokojen patrzył w przyszłość, gdy mówił:

"Czy bracia ze świętej wspólnoty z Tabennisi będą
jeszcze synami Ojca naszego Pachomiusza, meza
sprawiedliwego? Czy bęzie jeszcze ktoś, kto zapy-
ta swego bliźniego: "jaki jest sens tego tekstu?"
Czy powrócimy jeszcze, juz to do własnej pracy, juz
to do wozu, na droǵ, czy tez do recytowania słowa
Bożego, zgodnie z poleceniem naszego ojca?"33

Niestety, czarne przewidywania Teodora były w pełni uzasadnione. Wspólnota nie była już tą samą gromadą ludzi ogarniętych tym samym duchem, tą saną gorliwością, duchem wyrzeczenia i posłuszeństwa. Zmienili się ludzie, zmieniła się i mentalność kolejnych generacji mnichów, zmieniły się wreszcie warunki życia i działania Kościoła. Wielcy protagoniści pachomianizmu czuli, że coś nieuchwytnego zniknęło bezpowrotnie, coś, co stanowiło o ich oryginalności, co było racją ich bytu.

Niewiele zostało po pachomianach; jedyne kompletne dzieła to: Reguła, 11 listów Pachomiusza, Monita, 1 list Teodora, oraz "Liber"

32 Vita graeca prima 130, ed. F. Ifalkin/Sancti Pachomil Vitae graecae. Subsidia hagiographica 19, Bruxelles 1932/, 82.

33 Sancti Pachomii Vita sahidice scripta 6, Lefort, Les Vies Coptes... dz.cyt., 327 . 
Orsiesego, czyli akurat tyle, ile uratował św. Hieronim, dzięki tłumaczeniu na łacinę. Reszta to drobne fragmenty w języku koptyjskim i etiopskim.

Wydaje się jełnak, że mimo wszystko ocalało co najważniejsze, mianowicie oryginalna duchowośc, wyrastająca w całości z zafascynowania Biblią, z jakiegoś zapamiętania się w karmieniu się słowem Bożym, z odnoszenia wszystkiego do Pisma św. rachomianie sqz wciąż żymyn $i$ zachęcającym przykładem tego, jak studiować Biblię, by mieć ją w sobie wciąż mówiącą, przenikającą jak niewidzialne promieniowanie całe życie chrześcijanina, ocalającą i scalającą go w jego wewnętrznej tożsamości. Są oni wreszcie żywą, mimo wieków oudalenia, odpowiedzią na wciąż powracające pytanie o źródła autentycznej oùnowy, o sens i sztukę życia, wreszcie o możliwości uratowania naszego świata.

Ks. Ryszard Kurek - Tarnów

\section{BIBLICA ORIENTAZIONE DELLA MEDITAZIONE PACOMIANA /Sommario/}

La meditazione elaborata negli ambienti anacoretici assunse il significato di recitare a voce bassa, ed aveva come soggetto la parola di Dio. Quanto all'etimologia la parola "meditazione" deriva dal greco "melete"", e questa non e che traduzione dell'espressione ebraica "hāgāh" che significava: mormorare, brontolare, sussurrare, sospirare. Ne fu aggiunto ben presto il concetto di ruminare.

Arricchita cosi la "meditazione" esprimeva bene il desiderio dei monaci primitivi di nutrirsi della parola di Dio. Fu la meditazione che sminuzzava questo nutrimento, lo masticava, lo ruminava, riducendolo in pappa specifica per farlo nutrimento delle anime, una specie di comunione con Dio. Il cuore di monaco, imbevuto della Bibbia, trovava nella meditazione 11 suo riscaldamento e spinta alla preghiora tutta spontanea. I pacomiani meditavano proprio cosí, ma la loro meditazione aveva come sostegno il dovere di saper leggere e scrivere, e solo per poter personalmente accostarsi alla fonte divina. Il 1oro intero diventava così santuario della Parola eterna.

Ogni aprire bocca, dunque, assumeva il significato di traboccare delle parole bibliche e del linguaggio plasmato dalla Bibbia. É il messaggio dei pacomiani per 1 nostri tempi che stanno rivivendo la meditazione come ricerca dell'uomo nel trovare Dio. 